SAND94-8001

Unlimited Release

Printed January 1994

\title{
ENVIRONMENTAL PROTECTION \\ IMPLEMENTATION PLAN
}

\author{
David D. Brekke
}

Sandia National Laboratories/California

\begin{abstract}
This Environmental Protection Implementation Plan is intended to ensure that the environmental program objectives of Department of Energy Order 5400.1 are achieved at SNL/California.The Environmental Protection Implementation Plan serves as an aid to management and staff to implement new environmental programs in a timely manner.
\end{abstract}

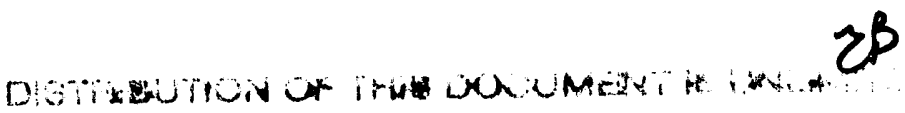


SANDIA NATIONAL. LABORATORIES/CALIFORNIA

\title{
ENVIRONMENTAL PROTECTION IMPLEMENTATION PLAN
}

\author{
For the Period:
}

November 9, 1993 to November 9, 1994

Prepared: October 1993

\author{
Prepared by: Environmental Protection Department, 8642 \\ Sandia National Laboratories/California \\ P. O. Box 969 , MS 9222 \\ Livermore, CA 94551-0969
}

Approved by:

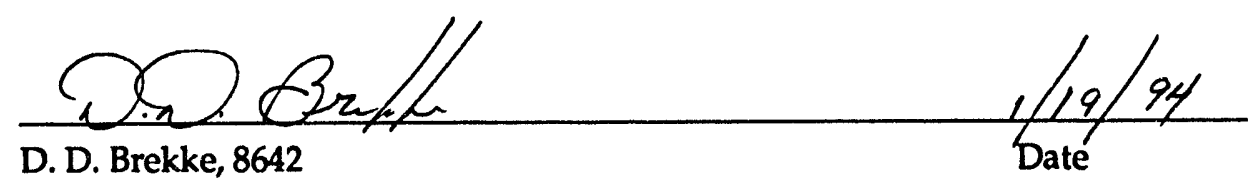

D. D. Brekke, 8642

Environmental Monitoring Program

Environmental Protection Department

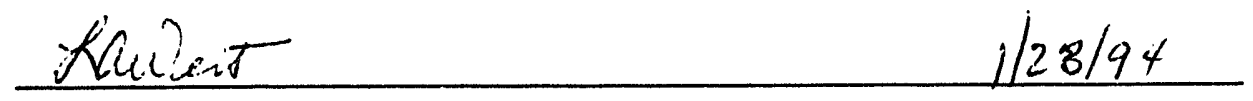

L. A. West, 8600

Date

Director, ES\&H and Facilities Center

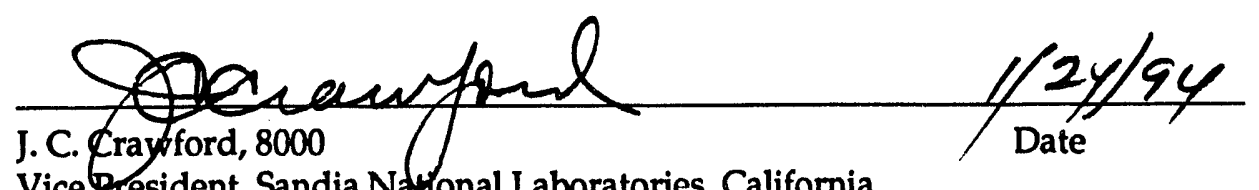

Vice President, Sandia Natronal Laboratories, California 


\section{TABLE OF CONTENTS}

1.0 Environmental Protection Program at SNL/California ................................................................7

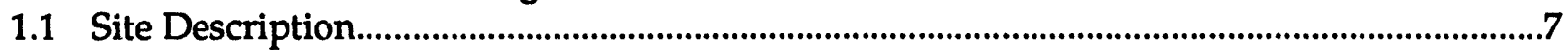

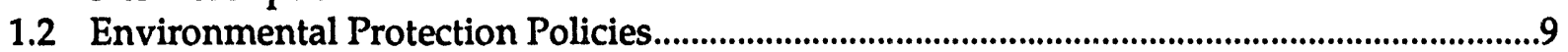

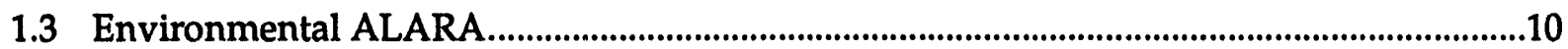

1.4 Environment, Safety, and Health Organization and Responsibilities .................................11

1.5 Environmental Protection Responsibilities ........................................................................15

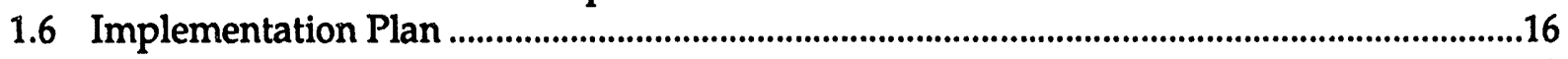

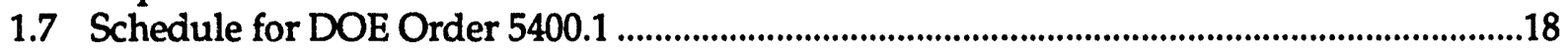

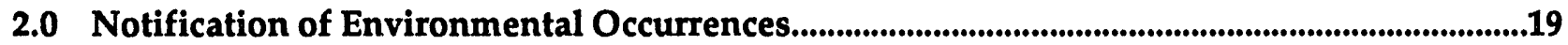

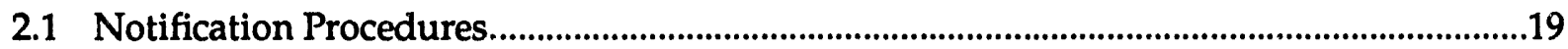

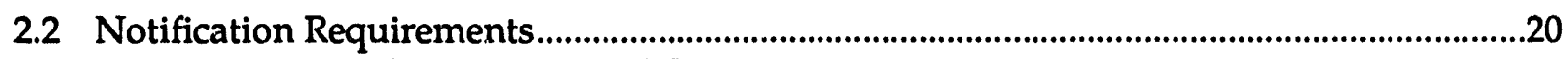

2.3 Documentation of Environmental Occurrences ...................................................................22

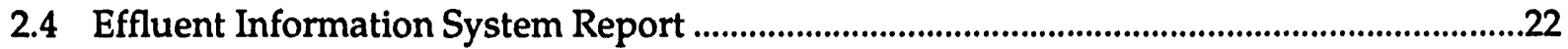

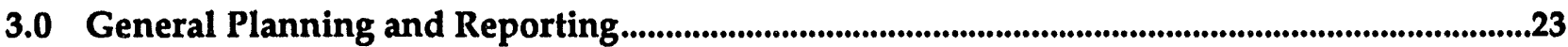

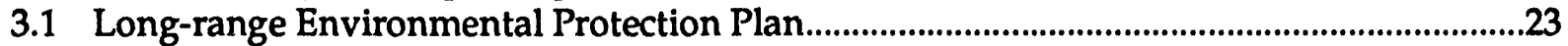

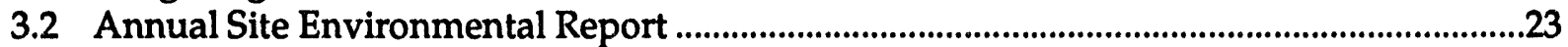

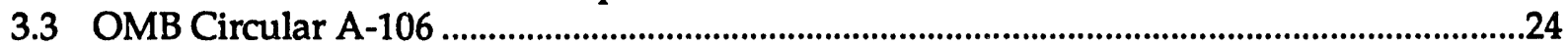

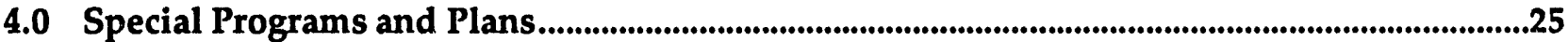

4.1 Groundwater Protection Management Program............................................................25

4.2 Waste Minimization Plan and Pollution Prevention Awareness Program ..........................25

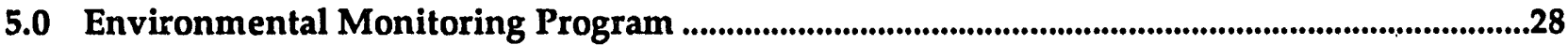

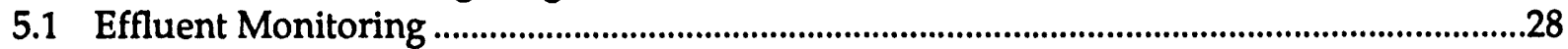

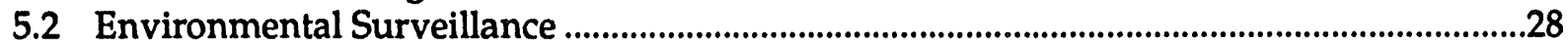

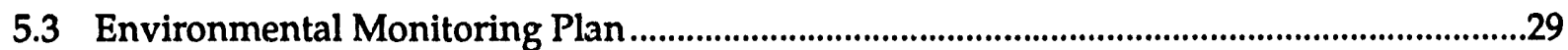

5.4 Environmental Monitoring Activities ....................................................................................31

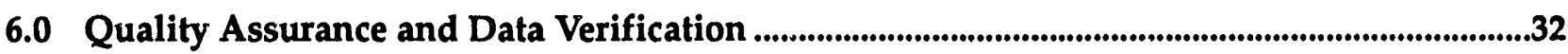

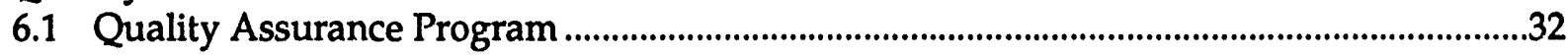

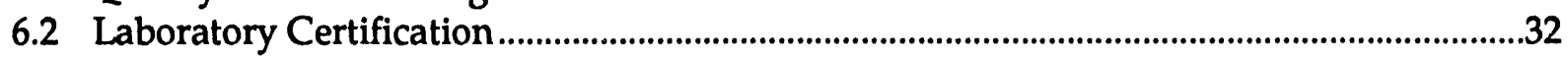

6.3 Department of Energy Laboratory Quality Assurance Program

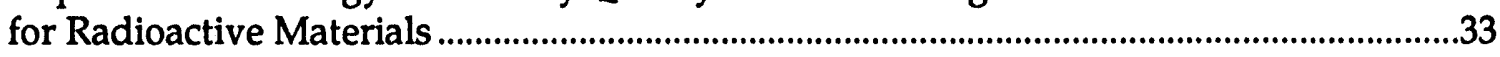

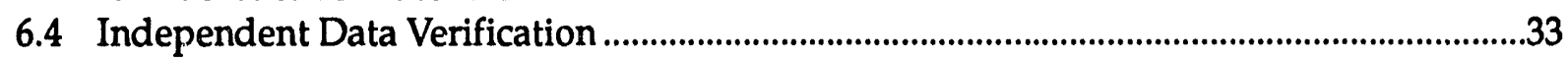

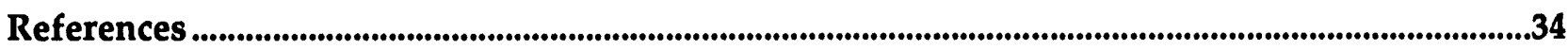

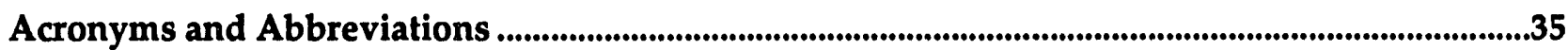

Figures and Tables

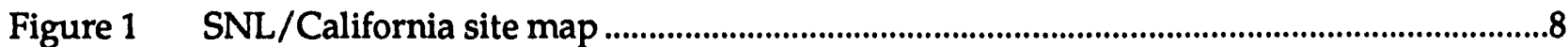

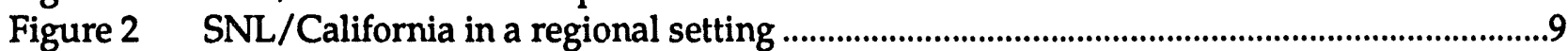

Figure 3 SNL/California Environment, Safety, and Health organizational chart .........................12

Figure 4 SNL./California Environmental Protection Department, Org. 8642, organizational chart........................................................................................

Table 1 SNL/California's DOE Order 5400.1 Compliance Schedule...........................................18 


\subsection{INTRODUCTION}

Sandia National Laboratories (SNL) at Livermore, California, is operated for the Department of Energy (DOE) by Sandia Corporation.

SNL/California's primary mission is conducting research and development in the interest of national security, with principal emphasis on nuclear weapon development and engineering, excluding the nuclear components. To carry out this mission, SNL/California has evolved into a multiprogram laboratory that maintains a leading position in a broad range of scientific and technical fields. SNL personnel also maintain close interaction with scientists and engineers at universities, in industry, and at other laboratories.

To fulfill its mission, SNL applies its expertise to the following:

1. research and development associated with weapon engineering for all levels and phases of the nuclear weapon life cycle;

2. other national-security-related tasks, including nuclear materials safeguards and security, treaty verification and control, intelligence on foreign technologies and weapon systems, waste management, and programs in support of the Department of Defense; and

3. research and development of the following:

a. fossil fuels, including coal, oil and gas;

b. conservation and renewable energy, mainly solar energy;

c. nuclear energy, principally waste management and reactor safety and reliability in support of the Nuclear Regulatory Commission;

d. magnetic confinement fusion energy, mainly on plasma/material interactions; and

e. fundamental energy research related to combustion, geosciences, and materials sciences.

\subsection{Site Description}

The SNL/California site covers $1.7 \mathrm{~km}^{2}$ (413 acres) of land located on the southeastern boundary of the City of Livermore (Fig. 1), in eastern Alameda County, $65 \mathrm{~km}$ ( 40 miles) east of San Francisco (Fig. 2). The site lies at the western base of the Altamont Hills, which form the eastern boundary of the Livermore Valley.

The Livermore Valley is an irregularly shaped lowland in the Diablo Range of the California Coastal Mountain Range. The valley is approximately $26 \mathrm{~km}$ (16 miles) long (east to west) and averages about $11 \mathrm{~km}$ ( 7 miles) wide. The valley floor slopes downward generally to the west at about $10 \mathrm{~m} / \mathrm{km}$ ( $50 \mathrm{ft}$. $/$ mile). The elevation is approximately $200 \mathrm{~m}$ ( 660

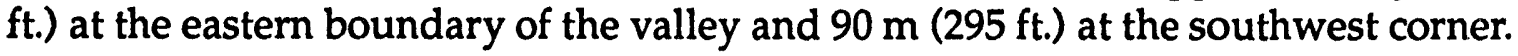

The Valley's major drainage is intermittent streams (arroyos). These arroyos generally carry water to the southwest end of the Valley and into the Alameda Creek near Sunol. Alameda Creek then continues on to the San Francisco Bay. 


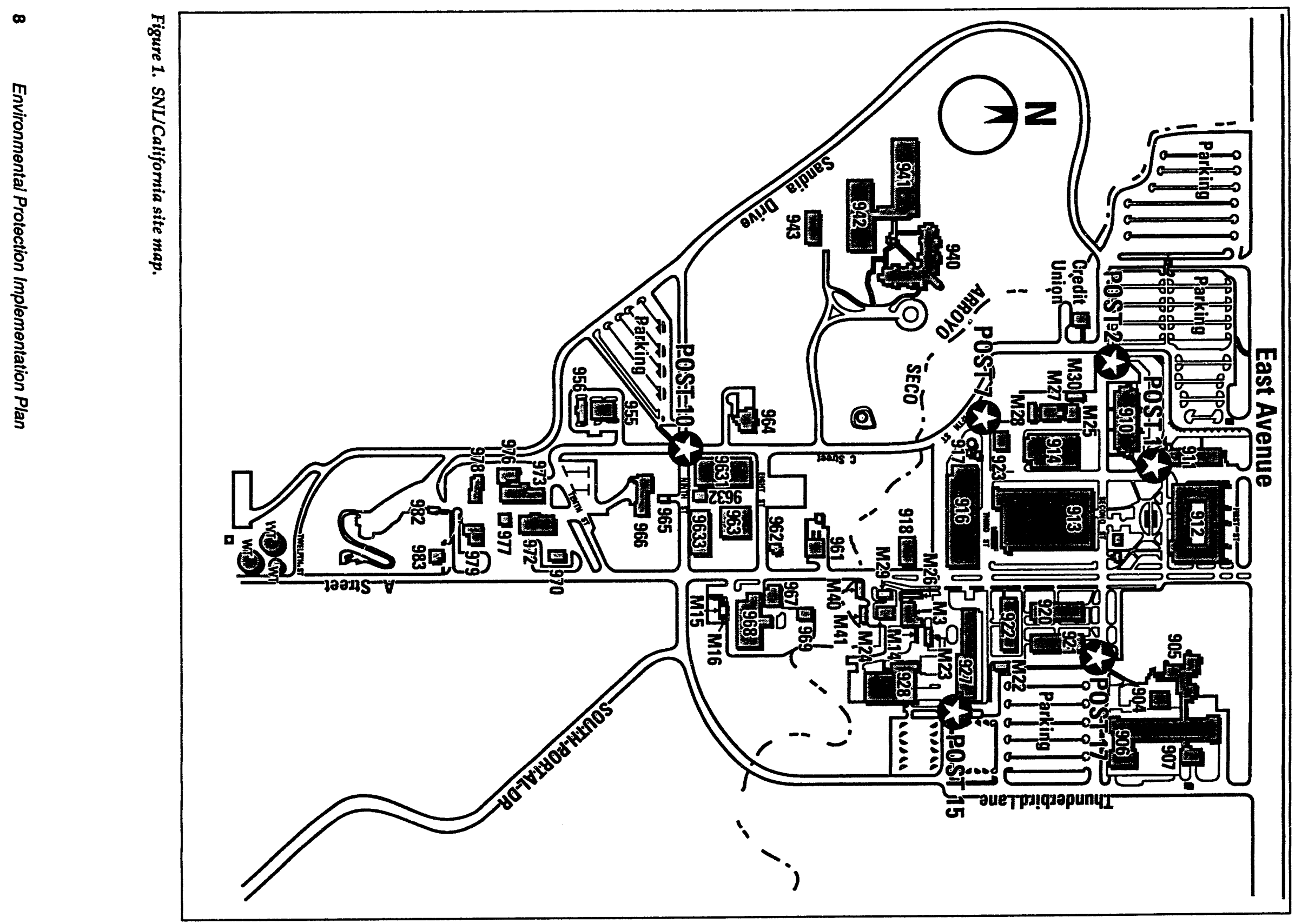




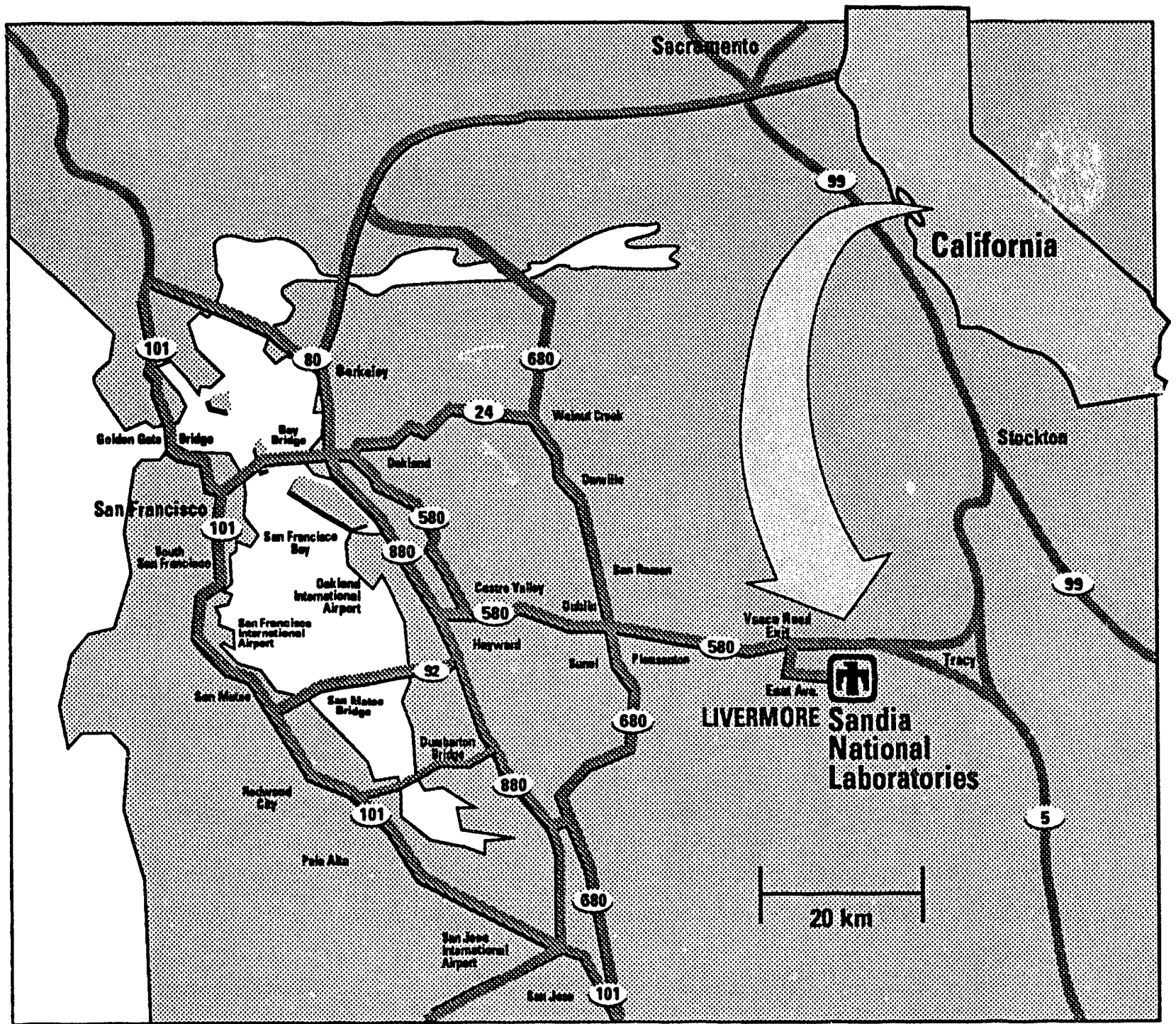

Figure 2. SNLCalifornia in a regional setting.

\subsection{Environmental Protection Policies}

Sandia National Laboratories, as part of the DOE complex, is committed to full compliance with all applicable environmental laws and regulations. This Environmental Protection Implementation Plan (EPIP) is intended to ensure that the environmental program objectives of DOE Order 5400.1 are achieved at SNL/California. ${ }^{1}$ The EPIP serves as an aid to management and staff to implement these programs in a timely manner. SNL's environment, safety, and health (ES\&H) policy, as stated in the ESEH Manual, is as follows:2

SNL considers the protection of the environinent, as well as humanifife and health to be its top pronty Conflicts between ESEH requirements ond other programinatic needs will be resolved to fully neet the ESEH requirements, Accordingly. SNI shall design prodicts ond conduct operations with the highest regard for the protection and preservation of the environ: ment and safety and health of its personnel, contractors, and the public. SNL shall ensure the. 


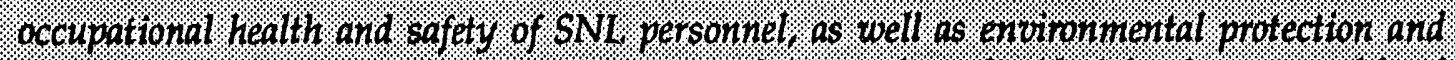
preservation throughout all operations by complying with opplicable federal. state and local: laws and regulations. DOE Orders, pernit agreements. orders, and consent decrees. SNIL shall make sure that contractors ond site visitors are fully informed of this Poltcy ont of theit.

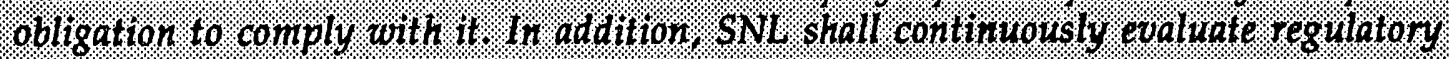
requitements, conporate policies, and customer needs, and shall adjust its operations io meet.

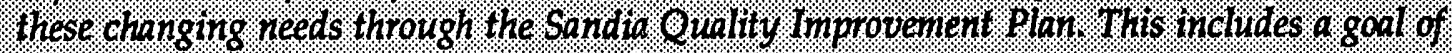
continuous improventit in ESEH processes.

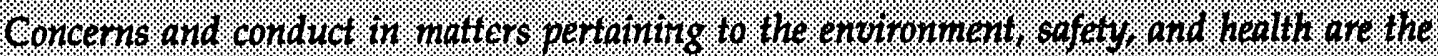
responsibility of all SNL enployees. on site contractors ond visitors. NO IOB IS WORE IMPORTANT THAN YOLR HEALTH. YOUR SATETY IND THE PROTECTION OF OUR ENVIRONMENT:

Primary responsibility for assuring compliance with ES\&H principles and procedures rests with line supervisors and those in charge of specific programs and experiments. To aid line supervisors in fulfilling this responsibility, Sandia maintains a staff of ES\&H professionals.

Long-standing DOE policy states that sites will comply with all applicable environmental statutes and regulations. On September 6, 1990, DOE signed an Agreement in Principle (AIP) with the State of California to provide California's citizens independent assurance that DOE sites in California are fulfilling their commitments to health, safety, and the environment. The AIP is part of a DOE effort to conduct operations with openness and full disclosure to the local community. To implement the AIP, DOE has agreed to provide the State access to its facilities, comprehensive monitoring data, and financial support. As deemed necessary, the State will independently monitor and oversee DOE sites in California.

\subsection{Environmental ALARA}

DOE Orders require that risks to the public and the environment be kept as low as reasonably achievable (ALARA). This aim is an essential part of corporate good citizenship and an element by which the quality of the Laboratories is judged.

Implementing Procedure IP-25, ALARA Program Implementation, specifies the formation of an ALARA Committee. ${ }^{3}$ The ALARA Committee will comprise representatives from the Health Protection Department, the Environmental Protection Department, the Component Technology Department, the Test Assembly Group, the Materials Technology Department, and the Physical Science Department. This committee will direct line management to establish annual ALARA goals. These goals will include the total radioactivity released to the environment in airborne and liquid effluents.

The ALARA Committee will also be responsible for reviewing Facilities Management designs. Review will include technical, economic, practical, and public policy issues. The review process will be formalized in an implementing procedure.

Another method by which ALARA concerns may be brought to the committee's attention is the National Environmental Policy Act (NEPA) review process. All major construction 
projects, changes in operations, and proposed new operations must be evaluated according to NEPA criteria. SNL/California has a formal NEPA Program for these evaluations. They are done by the NEPA Compliance Officer, in the Environmental Protection Department. The NEPA Compliance Officer is responsible for obtaining information from other organizations in the ES\&H and Facilities Center, as appropriate. The NEPA Compliance Officer will forward all documentation of projects with potential radiological impacts on the public or the environment to the ALARA Committee for review.

\subsection{Environment, Safety, and Health Organization and Respunsibilities}

At SNL, ES\&H is every employee's responsibility. ES\&H management combines technical experts (who are educated and/or experienced in specific ES\&H fields) with line personnel to implement ES\&H requirements throughout the Laboratories. An SNL ES\&H Council meets regularly to discuss ES\&H-related issues that impact the entire facility.

\subsubsection{Environment, Safety, and Health Organization}

To fulfill its ES\&H commitments, SNL has established a corporate-level ES\&H organization. This consists of an Environment, Safety, and Facilities Management Vice Presidency at SNL/New Mexico and other ES\&H support organizations. The ES\&H requirements are implemented using written ES\&H programs and procedures.

SNL/California augments the corporate program by maintaining its own site ES\&H organization. This organization develops and implements ES\&H programs and ensures compliance with regulations specific to the California site. SNL/California's ES\&H organizational structure is shown in Fig. 3.

To help assure ES\&H commitments are fulfilled, SNL/California has established a Management Assurance Department and a Vice Presidential ES\&H Council. The Management Assurance Department reports directly to the ES\&H and Facilities Center Director, helping him properly manage ES\&H at the site. This department also does internal audits and assists line organizations with self-assessment activities to assure that the site is fulfilling its ES\&H responsibilities. The Vice Presidential ES\&H Council helps track ES\&H compliance activities and implement ES\&H programs at SNL/California.

\subsubsection{Environment, Safety, and Health and Facilities Center, 8600}

An important aspect of the mission of the ES\&H and Facilities Center is to ensure the health and safety of SNL/California employees and the general public, and to protect the environment. This mission is fulfilled, in part, by helping SNL/California employees understand and comply with DOE Orders and their legal responsibilities under Federal, State, and local laws and regulations. The ES\&H and Facilities Center has three departments involved in ensuring workplace safety and protection of the environment: Health Protection, Environmental Protection, and Safety. An ES\&H quality assurance group reports directly to the Center Director and is functionally independent of the departments. The Environmental Protection Department is specifically responsible for this EPIP; therefore, its function is described below. 


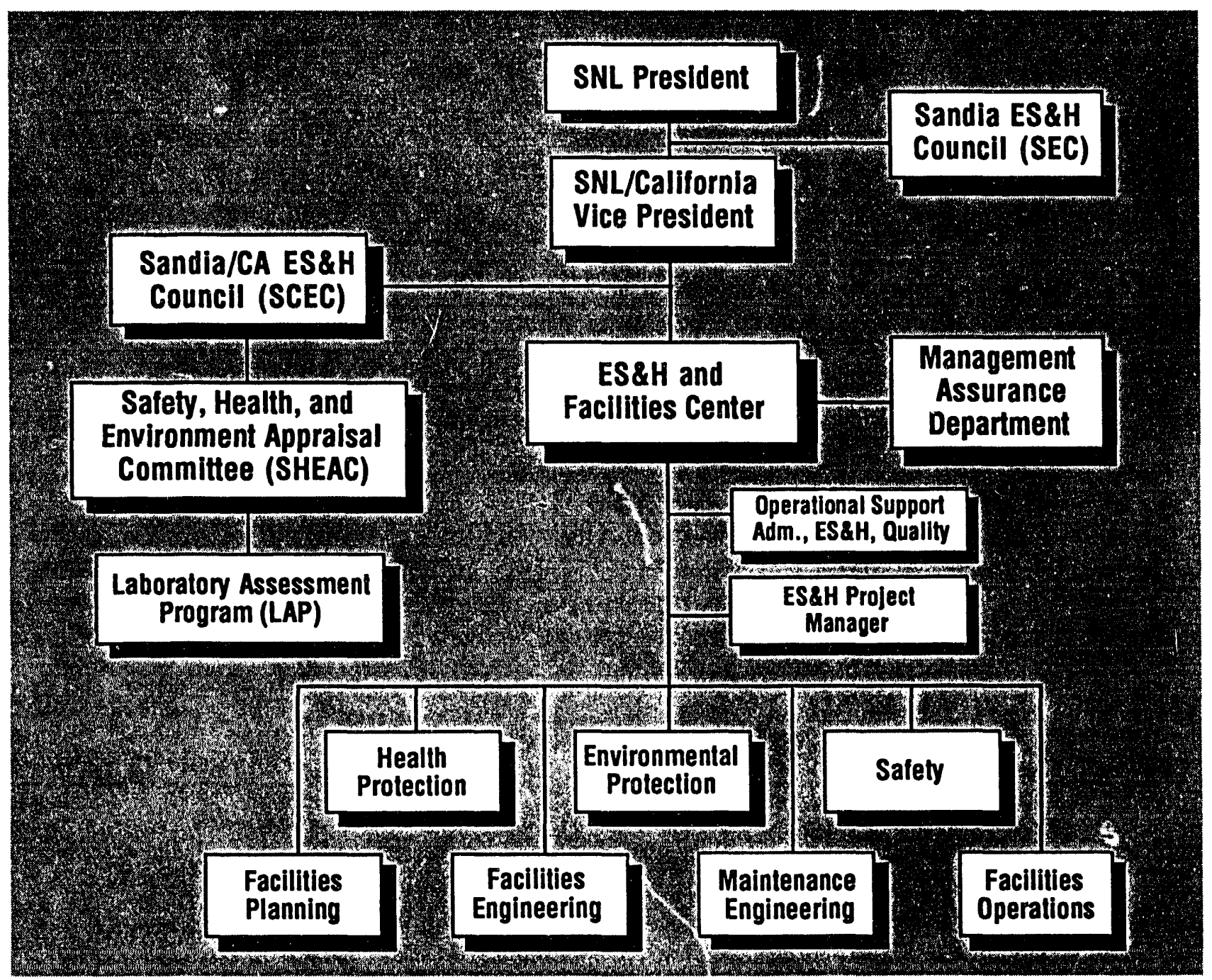

Figure 3. SNL/Califomia Environment, Safety, and Health organizational chart.

\subsubsection{Environmental Protection Department}

The Environmental Protection Department is responsible for ensuring that SNL/California operations have minimal impact on the natural environment. The department has programs in waste management, waste minimization, environmental technology, environmental monitoring, environmental remediation, air quality, and regulatory affairs (Fig. 4). Department staff ensure that emissions are within acceptable regulatory levels, that hazardous waste is disposed of safely and properly, that areas with known contamination are cleaned up and restored to a safe condition, and that permits and other documentation necessary for laboratory operations are prepared properly and submitted on time. The department coordinates environmental protection activities with line organizations, from conceptual design through project completion. This involvement assures an environmentally safe operation through administrative and engineering controls. 


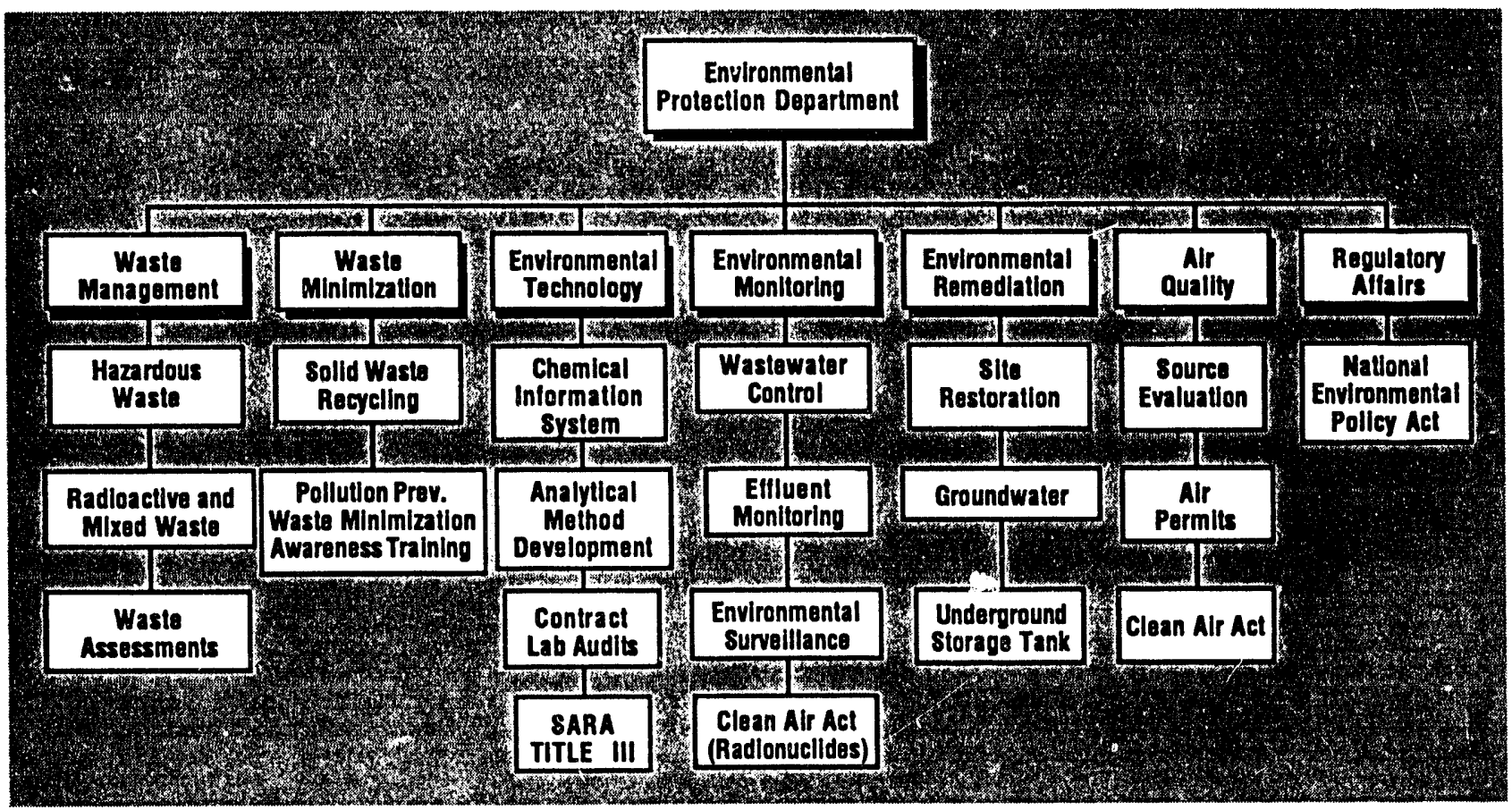

Figure 4. SNL/Califormia, Environmental Protection Department, Org. 8642, organizational chart.

\section{Waste Management}

The Waste Management Group manages hazardous, radioactive, energetic, infectious, and mixed wastes. Responsibilities include picking up, transporting, storing, and disposing of (off-site) wastes in accordance with Environmental Protection Agency (EPA) and State regulations. The Waste Management Group is also responsible for employee training in hazardous waste generation, disposal, and spill control and remediation. The only waste treatment processes done on-site are compaction (to reduce waste volume), consolidation and commingling. No transuranic or high-level waste is generated at this site. No hazardous waste has ever been disposed of on-site by SNL/California. This group aiso does process waste assessments for major hazardous waste generators, with the goal of reducing hazardous waste generation.

\section{Waste Minimization}

The Waste Minimization Program promotes the reduction of waste generated by site operations as much as possible. It coordinates source reduction and recycling. SNL/California has appointed a waste minimization coordinator to manage this program.

The Waste Minimization Group is responsible for SNL/California's Waste Minimization Program and employee training in waste minimization and reduction techniques. The Waste Minimization and Pollution Prevention Awareness Program represents an ongoing effort to make pollution prevention part of Sandia's operating philosophy. The coordinator manages the program and is responsible for program planning and employee awareness training in waste reduction and minimization methods.

Sandia follows DOE's policy of waste reduction-adopting a hierarchical approach. Waste must first be eliminated or minimized through source reduction. If possible, waste materi- 
als that cannot be eliminated or minimized are recycled (reused or reclaimed). All waste is treated to reduce volume, toxicity, or mobility before storage or disposal.

\section{Environmental Technology}

The Environmental Technology Group is responsible for a wide range of environmental support activities, including environmental chemical analyses, on-site laboratory quality assurance (ES\&H laboratory), audit of contract laboratories, and development of a sitewide chemical information management system. This system is designed to help SNL/California more effectively comply with Federal and State regulations and DOE Orders. It is a database that tracks chemical containers in facilities by bar-code labels. It provides detailed information to several programs: Employee Right-to-Know, Emergency Planning and Community Right-to-Know, Waste Minimization, Spill Information and Emergency Preparedness, Fire Protection, and California Proposition 65 Compliance. This system also maintains the site Material Safety Data Sheet (MSDS) library and can supply MSDSs online.

\section{Environmental Monitoring}

The Environmental Monitoring Group verifies that SNL/California complies with all Federal, State, and local regulations and DOE Orders governing emissions to the environment. The group monitors ambient air, wastewater discharges, and the general environment of the Laboratory and vicinity to verify compliance with established safety standards. The group prepares numerous reports, permit applications, and other documents to demonstrate compliance with various environmental regulations and DOE Orders. The group also provides training to the line organizations on issues concerning discharges to the air and sanitary sewer.

\section{Environmental Remediation}

The Environmental Remediation Group identifies, assesses, and treats hazardous material releases on-site. The group's primary focus is to fulfill SNL/California's responsibilities under the Comprehensive Environmental Response, Compensation, and Liability Act (CERCLA); however, it also addresses other environmental problems. This group is responsible for the underground storage tank program. SNL/California has two active environmental remediation sites: the Fuel Oil Spill site and the Navy Landfill. A third previously active site, the Trudell Auto Repair Shop, was cleaned up and officially closed in 1990. The Fuel Oil Spill site is undergoing preliminary tests in preparation for cleanup via bioremediation. A report on the Navy Landfill has been submitted to the State. The Environmental Remediation Group also samples wells throughout the site to monitor the condition of the groundwater.

\section{Air Quality}

The Air Quality Group is responsible for the regulatory compliance of all air emission sources at the SNL/California site. The group obtains permits or exemptions for all emission sources, as applicable. It also works with managers to formulate strategies to achieve compliance with any applicable air emissions regulations. 


\section{Requlatorv Affairs}

The Regulatory Affairs Group examines new projects/activities for compliance with NEPA. Proposed changes to existing conditions are evaluated to minimize their impact on the environment, workers, and the public.

\subsubsection{SNL/California Management Assurance Department}

The Management Assurance Department reports directly to the ES\&H and Facilities Center Director, helping him properly manage ES\&H at the site. This department also does internal audits and assists line organizations with self-assessment activities to assure that they are fulfilling their ES\&H responsibilities.

\subsubsection{SNL/California Vice Presidential Environment, Safety, and Health Councll}

The Vice Presidential ES\&H Council (SCEC) is chaired by the SNL/California Vice President. It includes the directors of the line organizations (centers) and staff members who have been assigned as center ES\&H coordinators. The SCEC serves as a forum for discussion of major ES\&H issues by senior management at the site and provides input into decisions made by the Vice President. It plays a top-level role in promoting, communicating, ind establishing a culture that recognizes ES\&H as top priority. The SCEC meets quarterly and keeps formal minutes.

\subsubsection{Self-Assessment Program}

SNL has a comprehensive system to assess and track ES\&H commitments. The Sandia ES\&H Self-Assessment Program consists of three key sub-programs: Appraisal, Performance Indicators, and Operating Experience Evaluation. The ES\&H Appraisal Program establishes an internal appraisal hierarchy consisting of independent appraisals, management surveillance, and line inspection activity. The independent appraisals are done under the auspices of organization 7001 (SNL/New Mexico), ES\&H Regulatory Assessments, which also provides the SNL tracking and lessons learned functions. The ES\&H Performance Indicator Program establishes a set of quantitative measures for DOE to evaluate and track the Laboratories' ES\&H performance. Line self-assessment is provided principally by the Management Surveillance Program, supplemented by line inspection activity as felt necessary by line management. The California Vice President (organization 8000 ) has established the Livermore Assessment Program (LAP) to fulfill this supplementary inspection requirement.

\subsection{Environmental Protection Responsibilities}

This section describes the organizations and individuals responsible for ensuring compliance with DOE Order 5400.1.1 Compliance includes incorporating the thirteen responsibilities required of the Head of the Field Organization, as identified in the Order [pgs. 12-14, paragraphs f.(1)-f.(13)]. Each responsibility is listed below in the context of how SNL/California fulfills that responsibility.

1. The SCEC is responsible for the ES\&H Program at SNL/California. 
2. Line organizations, with the help of the Environmental Protection Department, are responsible for ensuring that all SNL/California operations comply with applicable environmental laws and regulations.

3. The VP ES\&H coordinator, working with center coordinators in the line organizations and the Environmental F'rotection Department, facilitates implementation of the ES\&H Program.

4. The Exvironmental Protection Department is responsible for coordinating the rozis of ail required environmental permits for SNL/California's operathus:-

5. LAP (with the line organizations) is responsible for conducting internal environmental appraisals of SNL/California programs, projects, and facilities in accordance with DOE Order 5842.1B and other ES\&H requirements. 4

6. The Environmental Protection Department is responsible for establishing and maintaining liaison with appropriate Federal, regional, State, and local environmental officials to facilitate effective environmental management.

7. The ES\&H and Facilities Center is responsible for working with the Procurement Services (8534) and Facilities Engineering (8612) Departments to:

a. develop and implement programs that direct contractors to execute environmental protection compliance programs, and

b. provide oversight, confirmation, and independent verification of these contractor programs.

8. The Environinental Protection Department, under advisement of the ES\&H and Facilities; Center, is responsible for preparing long-range environmental protection plans.

9. The ES\&H and Facilities Center is responsible for ensuring that budget requests provide for required environmental protection upgrades and that corrective actions are consistent with the Office of Management and Budget (OMB) Circular A-106 report. ${ }^{5}$

10. The Environmental Protection Department is responsible for overseeing the preparation of the semiannual pollution abatement plans required by the OMB Circular A-106 report. 5

11. The Environmental Protection Department is responsible for providing DOE Headquarters $(D C E / H Q)$ all environmental information and documentation requested by $D O E$.

12. Any SNL employee has the authority and the responsibility to curtail or suspend any operation that poses a clear and present danger to members of the public or the environment.

13. The ES\&H and Facilities Center and the Public Relations Office (8522) are responsible for providing public information and educational programs concerning SNL's environmental protection programs.

\subsection{Implementation Plan}

ES\&H concerns are built into prc grams from planning to completion. Projects are reviewed by the appropriate authority - the NEPA coordinator, the Health Physics Group, the Environmental Monitoring Group, and the Waste Minimization Group. The aim is to reduce 
risks to employees, the public, and the environment to the lowest reasonable levels. The procedures used to implement ES\&H requirements are identified below.

\subsubsection{Early Planning}

In conjunction with the requirement for NEPA review, plans for projects, processes, tests, and facilities are submitted for review to the ES\&H and Facilities Center during the conceptual stage. This procedure assures that all risks are considered, controls or mitigation of all hazards are planned, pollution prevention and waste minimization are considered, and Safe Operating Procedures (SOPs) are prepared and approved before operations begin. To assure that new operations, procedures, and facilities work as intended, ES\&H concerns are addressed early in the planning stages.

\subsubsection{Manager Responsibilities}

Managers have the following responsibilities:

1. Participate as a member of the SCEC (as required);

2. Implement the SNL ES\&H policy and programs, establish appropriate procedures within their departments, and communicate SNL's ES\&H policy and expectations to all employees;

3. Identify and assign department staff to implement the ES\&H programs and procedures within the organization and subordinate organizations;

4. Approve Preliminary Hazard Assessments, Qualitative Risk Assessments, ES\&H SOPs for hazard control, and corrective action reports;

5. Set ES\&H goals for the department and the metrics used to measure progress toward those goals;

6. Establish a manager-led self-appraisal activity; participate in management and functional appraisals of facilities and project activities in accordance with the Vice Presidential Self-Assessment Plan;

7. Perform management surveillance of all facilities or project activities within the department at least semiannually;

8. Hold a department meeting semiannually to discuss ES\&H performance with respect to the metrics to draw out employees' ES\&H concerns or issues;

9. Include ES\&H performance of staff in the annual performance appraisal and salary review process;

10. Maintain ES\&H documentation, including the ESEH Manual and Management Assurance Notebook.

\subsubsection{Employee Training}

Department managers are responsible for making sure that all employees and contractors are trained appropriately in ES\&H. The ES\&H Training Group (part of the Education and Affirmative Action Department) designs, develops, and presents all Laboratory-wide ES\&H training for employees, contractors, and visitors. As needed, the ES\&H Training Group may request assistance from line organizations or contractors with acknowledged expertise. This includes developing qualification guidelines for instructors. The ES\&H Training Group also maintains the control database of ES\&H training records. 


\subsection{Schedule for DOE Order 5400.1}

Table 1 contains SNL/California's schedule for complying with the reporting requirements of DOE Order 5400.1.1
Table 1. SNL/California's DOE Order 5400.1 Compliance Schedule

\begin{tabular}{|c|c|c|}
\hline Reportiplan & Due pate. & Roviowiupdate \\
\hline Implemeniation Plan. & $11 / 9 / 89$. & nonorannual \\
\hline OMB Circular A.106. & semiannual: & none/semiannual. \\
\hline Site Environmental Report. & Annual (6) 1 ) & nonelannual \\
\hline Groundwater Protection Management Program Plan. & $5 \% 9 / 90$ & annuavevery 3 years \\
\hline $\begin{array}{l}\text { Waste Minimization and } \\
\text { Pollution Prevention } \\
\text { Awareness Program Plan. }\end{array}$ & $11 / 1 / 91$. & annuallevery 3 years \\
\hline Environmental Monitoring Plan & $1 / 19 / 91$ & annuavevery 3 yoars \\
\hline
\end{tabular}




\subsection{NOTIFICATION OF ENVIRONMENTAL OCCURRENCES}

Pursuant to DOE Orders 5400.1,5484.1, and 5000.3B, SNL/California, as a DOE-operating contractor, is responsible for appropriately reporting environmentally significant events. $1,6,7$ SNL/California will comply with the notification criteria contained in the DOE emergency preparedness orders (DOE 5500 series). Various Federal, State, and local laws and regulations also require SNL/California to report environmentally significant occurrences.

\subsection{Notification Procedures}

SNL/California has established procedures for notifying DOE and appropriate regulatory agencies of environmental occurrences. The notification procedures are described below.

\subsubsection{SNL Line Organizations}

The line organizations have been instructed to report environmental incidents of any type to the ES ${ }^{e_{-}} \mathrm{H}$ Hotline at SNL/California. The Occurrence Reporting Group of the Safety Department provides training every two years in occurrence reporting procedures and responsibilities to all SNL/California employees and contractors.

\subsubsection{SNL/California ES\&H and Facilities Center}

The Occurrence Reporting Program in the Safety Department at SNL/California is responsible for evaluating incidents and determining the appropriate level of notification. The ES\&H and Facilities Center has developed and maintains the SNL/California Emergency Preparedness Plan. This Plan includes Emergency Plan Implementation Procedures, which address notification responsibilities. If necessary, the ES\&H and Facilities Center will notify the DOE Albuquerque Operations, Kirtland Area Office (DOE/AL/KAO); SNL/New Mexico organizations; and other agencies, as appropriate. Responsibility for notifying external agencies is discussed later in this section.

\subsubsection{Department of Energy Albuquerque Operations Kirtland Area Office}

$\mathrm{DOE} / \mathrm{AL} / \mathrm{KAO}$ is responsible for reporting events to the DOE/AL Emergency Operations Center (EOC). DOE/AL/KAO acts as liaison between SNL/California and other Federal, State, and local agencies.

\subsubsection{Department of Energy Albuquerque Operations Emergency Operations Center}

If necessary, the DOE/AL EOC will notify the DOE/HQ EOC, which will in turn, notify the appropriate Headquarter's Program Office and the Assistant Secretary for ES\&H.

\subsubsection{Reporting Occurrences or Complaints After Working Hours}

If an event or condition requires immediate attention or emergency response, the employee involved is to call the Sandia emergency phone number, ext. 911. This extension connects to the Central Alarm System (CAS), which will dispatch the appropriate emergency response personnel. The CAS then notifies the appropriate Sandia Occurrence Investigator (an OI is available 24 hours a day). 
If an event or condition does not require emergency response, employees are to call the ES\&H hotline, ext. 4-ES\&H (4-3724) and report it to an OI. If an OI is not on-site, the call will automatically forward to the CAS, who can notify the appropriate OI 24 hours a day.

The OI determines if the event or condition is reportable under DOE Order 5000.3B. If it is, the OI notifies the appropriate facility manager, and the occurrence is reported to DOE/AL/KAO, DOE/AL EOC, DOE/HQ (Assistant Secretary for Defense ProgramsDP-1), and SNL/New Mexico, as necessary. If it is not reportable per DOE 5000.3B, or if the call is a complaint rather than a report of an occurrence, the OI will follow up to see that appropriate action is taken to close out the issue.

\subsection{Notification Requirements}

DOE Orders clearly state that DOE operations will be conducted in full compliance with all applicable environmental laws and regulations. SNL/California is committed to this policy. Proper communication is a vital component of this commitment. SNL/California has policies and procedures to ensure proper and timely notification of environmental occurrences.

Operations at SNL/California are regulated under a wide range of environmental statutes. The type and magnitude of an environmental occurrence dictates which agencies are to be notified. Agencies potentially involved in emergency notification include:

- Lead DOE Agency (any environmental occurrence)

- National Response Center (CERCLA Reportable Quantities)

- Office of Emergency Services (Resource Conservation and Recovery ActRCRA, State, CERCLA)

- U.S. EPA

- California EPA (Cal-EPA)

- U.S. Coast Guard

- U.S. Department of Transportation (highway spills)

- San Francisco Bay Area Regional Water Quality Control Board (RWQCB)

- Bay Area Air Quality Management District (BAAQMD)

- Alameda County

- City of Livermore

- California Departnent of Health Services (including AIP Program)

\subsubsection{Department of Energy}

\section{General Requirements for Notification}

SNL/California will notify DOE of significant environmental occurrences and significant "near misses" in accordance with the requirements of DOE Orders 5484.1 and 5000.3B.6,7 The ES\&H and Facilities Center at SNL/California is responsible for appropriately notifying DOE/AL/KAO. DOE/HQ will be notified through DOE/AL/KAO. SNL/California will also concurrently notify $\mathrm{DOE} / \mathrm{AL} / \mathrm{KAO}$ any time an environmental occurrence is reported to any outside agency.

DOE Order 5484.1 provides "Summary Charts for Accident Notification, Investigation, and Reporting." 6 This quick reference, as well as the complete guidance in the Order, will be used in determining the appropriate level of notification. 


\section{Occurrence Reports}

Occurrence reports (ORs) are required for any off-normal or unplanned event having programmatic significance, such that it adversely affects or potentially affects performance, reliability, or safety of a facility. An example is a "near miss," a situation that could have resulted in an accident. The Occurrence Reporting Group is responsible for complying with the OR requirements described in DOE Order 5000.3B.7

Events or conditions significant enough to require an OR will be reported to DOE in accordance with the time requirements specified in DOE Order 5000.3B. All reportable incidents require the facility manager to submit a written report to DOE within 24 hours. Depending on the severity of the occurrence, oral notification to DOE/HQ and DOE/AL/KAO may be required within 15 minutes to 2 hours of the incident.

\subsubsection{Environmental Protection Agency}

The EPA has established emergency notification requirements published in Title 40, Code of Federal Regulations (CFR), Parts 112, 117 and 302 (CERCLA). ${ }^{8}$ Under CERCLA, SNL/California, (through DOE) will report any hazardous pollutant release in excess of the reportable quantity to the National Response Center within 24 hours.

The EPA has established reportable quantities for specific chemicals and radionuclides. The SNL/California Environmental Protection Department is responsible for maintaining the list of reportable quantities. Line organizations are responsible for reporting all releases of one pint/one pound or more to the Environmental Protection Department. The Environmental Protection Department evaluates all releases and determines the appropriate level of notification. An unplanned release that exceeds a reportable quantity must be reported to the National Response Center and to DOE under the requirements of DOE Order 5000.3B. Personnel from the Environmental Protection Department will immediately notify the Director (8600), the Department Managers (8641, 8642, and 8643), and the OI, who will ensure that DOE is notified per DOE Order 5000.3B requirements.

\subsubsection{State of California Bay Area Air Quality Management District}

$\mathrm{SNL} /$ California is required to notify the BAAQMD of any excess air emission or system failure, defined as:

- a failure of pollution abatement equipment resulting in an unplanned release to the atmosphere;

- an unplanned release to the atmosphere of a National Emission Standards for Hazardous Air Pollutants (NESHAPs) regulated material that exceeds the reportable quantity; 9 or

- a violation of the requirements stated in any air discharge permit held by SNL/California.

An unplanned air release that requires reporting to the BAAQMD is reportable to DOE under DOE Order 5000.3B requirements. The Air Quality Program Manager from the Environmental Protection Department will notify the Department Managers (8641, 8642, and 8643) and the OI, who will ensure that DOE is notified. 


\subsubsection{City of Livermore Water Reclamation Plant}

The Clean Water Act (CWA) establishes standards for industrial discharges to waterways and Publicly-owned Treatment Works (POTWs). SNL/California holds a discharge permit issued by the City of Livermore Water Reclamation Plant (LWRP). This permit requires SNL/California to notify the LWRP of any discharge that exceeds permit limits, including any release that may cause harm to treatment plant operations.

The LWRP will be notified two ways:

1. Once the discharge has been verified to have exceeded permit limits, it is reportable to the LWRP and to DOE unc'er the requirements of SNL/California's Wastewater Discharge Permit and DOE Order 5000.3B. The knowledgeable Environmental Protection Department engineer will immediately notify the LWRP and an OI, who will ensure that DOE is notified.

2. Within 30 days, the SNL/California Environmental Protection Department will submit a written investigation report of the incident to DOE/AL/KAO for KAO to forward to the LWRP.

\subsection{Documentation of Environmental Occurrences}

\subsubsection{Department of Energy Requirements}

Following an environmental occurrence, SNL/California will prepare a written report in accordance with the requirements of DOE Orders 5484.1 and 5000.3B.6,7 The appropriate facility manager is responsible for ensuring that the reports are electronically transmitted to the Occurrence Report and Processing System (ORPS) database. The appropriate ES\&H department at SNL/California is responsible for maintaining evidence files and copies of all reports. These reports will be made available to auditors and regulatory agencies.

\subsubsection{Annual Summary and Public Disclosure}

Environmental occurrences will be summarized in the annual Site Environmental Report. 10 This report is made available to DOE, regulatory agencies, and the general public.

\subsection{Effluent Information System Report}

The DOE Effluent Information System (EIS) manages a database of radiological effluents released from DOE facilities. SNL/California measures and maintains records of radioactivity discharged in liquid and airborne effluent streams. As in the past, SNL/California will prepare the necessary radioactive effluent and on-site discharge data reports.

At the end of each calendar year, the Environmental Monitoring Program at SNL/California summarizes radiological emissions from the site. A DOE Form F-5821.1 is completed for each discharge point. The completed forms are submitted to DOE/AL/KAO and, once approved, are forwarded to:

EG\&G Idaho, Inc.

Waste Management Program

Idaho Falls, ID 


\subsection{GENERAL PLANNING AND REPORTING}

\subsection{Long-range Environmental Protection Plan}

Chapter III of DOE Order 5400.1 requires that each field organization develop a long-range environmental protection plan. 1 This plan should define specific environmental objectives. It should outline strategies for attaining those objectives, to include budgetary and staff resources, and a schedule for accomplishing established milestones.

SNL/California satisfies this requirement by providing information for DOE's Environmental Restoration and Waste Management Five-Year Plan..$^{11}$ This information is prepared by the Environmental Protection Department.

\subsection{Annual Site Environmental Report}

\subsubsection{Purpose}

DOE Orders 5400.1 and 5484.1 require each DOE site to prepare an annual summary environmental report. This report is prepared by the Environmental Protection Department and is approved by DOE/AL. The final draft is delivered to DOE/HQ (EH-1) by June 1 of the following year.

\subsubsection{Site Environmental Report Preparation}

Preparation of the annual environmental report is an ongoing process at SNL/California. Its format conforms to the requirements of Chapter II, Section 4 of DOE Order 5400.1.1

The Site Environmental Report documents all significant environmental activities throughout the year. ${ }^{10}$ It presents effluent and environmental monitoring data and discusses the Environmental Restoration Program and other environmental protection activities. Results of a radiological dose assessment, done to evaluate potential impacts on the general public, are included. The report also evaluates SNL/California's compliance records according to applicable environmental standards and includes a compliance summary section, which discusses any areas of noncompliance. The report's major emphasis is environmental management performance, which is evaluated by how well SNL/California's environmental protection activities comply with environmental laws and regulations. This section expresses Sandia's efforts to continually improve its corporate citizenship. In addition, Sandia is working to make the document easier for the general public to understand.

\subsubsection{Site Environmental Report Format}

DOE Order 5400.1 significantly expands the site environmental report's scope and format. Thus, the Site Environmental Report has been restructured to conform with DOE Order 5400.1, Attachment II-1, "Suggested Content and Format for Annual Environmental Reports." Greater emphasis is placed on the following items:

1. evaluating site environmental management performance;

2. interpreting data in light of regulatory standards;

3. providing greater coverage of environmental protection activities; and

4. making the information easier for the general public to understand. 


\subsubsection{Organizations Involved In Report Production}

Preparation of the Site Environmental Report is a cooperative effort among several organizations. The Environmental Protection Department holds overall responsibility for documenting all relevant environmental protection activities in the calendar year and using that information to produce the report. The final draft of the report is delivered to DOE/HQ by June 1 of the following year.

Off-site monitoring in the vicinity of SNL/California is conducted by LLNL's Environmental Monitoring Section (EMS). The EMS transmits the monitoring data to the SNL/California Environmental Protection Department for review and inclusion in the Site Environmental Report. The arrangement for environmental monitoring between SNL/California and LLNL is discussed further in Section 5.0.

Upon completion, the report is reviewed by SNL/California management. It is forwarded to DOE/AL/KAO for further review and approval. Once the report is approved, it is submitted to DOE/HQ.

\subsection{OMB Circular A-106}

The Environmental Protection Department updates the OMB Circular A-106 report semiannually as required by Executive Order 12088.5,12 It is submitted to DOE/HQ on December 15 and June 1 of each year. Environmental corrective actions and associated budgetary requirements are incorporated into the A-106 report using the guidance provided. Each discipline in the Environmental Protection Department is consulted to gather and analyze the data required for the A-106 report. As appropriate, other SNL/California organizations are consulted for additional input. The information in this report correlates with the information in DOE's Five-Year Plan.11 


\subsection{SPECIAL PROGRAMS AND PLANS}

\subsection{Groundwater Protection Management Program}

Under DOE Order 5400.1, SNL/California is required to establish a program for groundwater protection management. ${ }^{1}$ The Environmental Protection Department developed and implemented a Groundwater Protection Management Program Plan (GPMPP) in May 1990.13 The plan is reviewed annually and updated at a minimum of once every three years. Additional budget, if necessary, will be requested through the regular budgetary process.

To avoid duplication of effort, Sandia may use existing plans, permits, and other technical compliance documents, in whole or in part, to satisfy GPMPP requirements. These may include documents prepared to ensure compliance with environmental protection acts, to include the Safe Drinking Water Act (SDWA), RCRA, CERCLA, CWA, and local regulatory acts, such as the Porter-Cologne Water Quality Control Act and Safe Drinking Water and Toxic Enforcement Act (Prop. 65).

DOE Order 5400.1 requires completion of a groundwater monitoring plan to be included as part of the GPMPP. SNL/California's groundwater monitoring plan incorporates elements of the ongoing groundwater monitoring program developed to meet the requirements of the Environmental Restoration Program. This program is ongoing at SNL/California, in compliance with RWQCB Compliance Order 88-142 (which was updated by Compliance Order 88-184). ${ }^{14,15}$

\subsection{Waste Minimization and Pollution Prevention Awareness Program}

The Environmental Protection Department completed a Waste Minimization and Pollution Prevention Awareness Program Plan in May 1991.16 DOE, EPA, and Cal-EPA guidance was used in developing this plan.

As part of the waste minimization effort, SNL/California has appointed a full-time waste minimization coordinator in the Environmental Protection Department. This person is responsible for coordinating site-wide waste minimization activities.

Sandia's Waste Minimization and Pollution Prevention Awareness Program is an organized, comprehensive, and continual effort to reduce waste generation and to eliminate or minimize pollutant releases to all environmental media from all aspects of Sandia's operations. These efforts offer increased protection of public health and the environment. They also yield the following benefits:

1. reduce waste management and compliance costs,

2. reduce resource usage,

3. improve product yields,

4. reduce or eliminate inventories and the potential for releases of hazardous chemicals reportable under the Emergency Planning and Community Rightto-Know Act, and

5. reduce or eliminate the potential for civil and criminal liabilities under environmental laws. 
The program reflects the goals and policies for waste minimization of this organization and represents an ongoing effort to make pollution prevention part of Sandia's operating philosophy. In accordance with the DOE policy, a hierarchical approach to waste reduction has been adopted and is applied to all types of waste.

The first principle of waste minimization is eliminating or minimizing waste generation through source reduction. If possible, waste materials that cannot be eliminated or minimized are recycled (i.e., used, reused, or reclaimed). To the greatest extent possible, all waste is treated to reduce volume, toxicity, or mobility before storage or disposal.

\subsubsection{Strategy}

The guidance and the regulatory requirements for waste minimization and pollution prevention at Sandia are documented in a formal Waste Minimization and Pollution Prevention Awareness Program Plan.16 Site-specific implementation procedures have been developed. The procedures are designed to obtain accurate and current information on waste stream generation and waste management costs. This information provides the basis for implementing specific waste minimization techniques and technologies. The procedures include ways to collect information, evaluate options, and identify cost-effective waste minimization techniques. The essential elements of the strategy are to:

1. create an organization that comprises line and staff representatives who will develop and administer the waste minimization program,

2. define targets of waste to reduce, and

3. develop a method for tracking the performance and progress of the program.

The Waste Minimization and Pollution Prevention Awareness Program's objectives are to:

- foster a philosophy of conserving resources and creating a minimum of waste and pollution in achieving strategic objectives;

- promote the use of nonhazardous materials in operations to minimize the potential risks to human health and the environment;

- reduce or eliminate waste generation through product substitution, product reformulation, process modification, improved housekeeping, and on-site closed-loop recycling to minimize adverse effects on the air, water, and land;

- enhance communication of waste minimization objectives, goals, and ideas laterally and vertically among organizations;

- characterize non-hazardous waste streams and develop a baseline of waste generation data;

- identify and implement methods and technologies for waste minimization;

- target policies, procedures, or practices that may inhibit waste minimization;

- create incentives for pollution prevention;

- develop and implement employee pollution prevention awareness programs;

- collect and exchange waste minimization information through technology transfer, outreach, and educational networks;

- develop means for fully disseminating technological information to site users;

- increase employee awareness of pollution prevention goals, objectives, and methods;

- develop specific goals and schedules for waste minimization activities; and

- comply with Federal and State regulations and DOE requirements for minimization. 


\subsubsection{Organization and Staff Respons/billties}

The Waste Minimization Steering Committee (WMSC) has been created to oversee the implementation of the Waste Minimization and Pollution Prevention Awareness Program. Members of WMSC and their responsibilities are described below. WMSC has a project structure, i.e., representatives remain members of their own line organizations in a matrixmanagement system. The WMSC comprises the chair, site coordinators, one line representative from each vice presidency, and support representatives and contractors, as needed.

\section{WMSC Chair}

A WMSC chair, appointed by the vice president in charge of ES\&H, has overall responsibility for the corporate Waste Minimization and Pollution Prevention Awareness Program.

Waste Minimization and Pollution Prevention Awareness Program Site Coordinators The site coordinators are responsible for developing, directing, implementing, and documenting the Waste Minimization and Pollution Prevention Awareness Program.

\section{Line Oroanlzation WMSC Representatives}

Line WMSC representatives help line organizations plan, organize, and direct activities that will help them meet their responsibilities. The line representatives also examine proposed new projects (with the assistance of project staff) for pollution prevention opportunities. They provide the critical interface between the line organizations and waste minimization site coordinators.

\section{Support Representatives}

Support representatives (from Purchasing, Property Management, Finance, Industrial Hygiene, Health Physics, Facilities, Public Relations, Safety, and Training) are available to help the WMSC as needed. These support personnel represent a resource to which the line representatives can turn for advice and assistance.

\section{Line Oroanizations}

Responsibility for waste minimization and pollution prevention rests with line organizations (waste generators). Line organizations are responsible for developing and maintaining detailed waste assessments, identifying pollution prevention opportunities, providing necessary information for waste characterization and certification, obtaining guidance on regulatory and waste management requirements from Environmental Protection Department personnel, and implementing pollution prevention strategies and technologies.

\section{Individuals}

All Sandians are responsible for:

- understanding the Waste Minimization and Pollution Prevention Awareness Program;

- practicing the concepts of pollution prevention in their activities; and

- informing their WMSC representative of any anticipated new waste streams or changes in existing waste streams. 


\subsection{ENIVIRONMENTAL MONITORING PROGRAM}

The Environmental Protection Department is responsible for the Environmental Monitoring Program. This program ensures that SNL/California complies with all Federal, State, and local regulations and DOE Orders regarding emissions to the environment. The Environmental Monitoring Group is responsible for monitoring the general environment of the Laboratory and vicinity to verify compliance with established environmental standards, to assess potential impacts to the public and the environment from site operations, and to ensure that site operations do not degrade the environment.

Environmental monitoring at SNL/California consists of three major parts:

- airborne and liquid effluent monitoring,

- meteorological monitoring, and

- environmental surveillance.

\subsection{Effluent Monitoring}

Effluent monitoring is the collection and analysis of samples or direct measurements of liquid and gaseous effluents for the purpose of characterizing and quantifying contaminants released.

Airborne and liquid effluents are monitored to ensure compliance with established limits for release of pollutants into the atmosphere or bodies of water. At SNL/California, the pollutant of primary concern being released to the atmosphere is tritium from the Tritium Research Laboratory (TRL). Accordingly, the TRL stack is monitored continuously. The data are used to calculate potential doses to people off-site.

The only water pathways are discharges to the sanitary sewer system and surface runoff to the storm sewer system. These pathways are monitored for pollutants that could possibly enter the environment via the pathway. Besides ensuring that release limits are not exceeded, these data are used as a warning system to ensure that pollutants are not released in sufficient concentrations to affect the operations at the LWRP. In the event of such discharges, both LLNL and the LWRP are notified. Sandia discharges no liquid effluents directly to the ground, arroyo, or any other surface water body.

\subsection{Environmental Surveillance}

Environmental surveillance involves the collection and analysis of samples of environmental media (e.g., air, water, soil, foodstuffs, etc.). It is conducted to verify that emission controls are effective in preserving the local environs, and to check for possible buildup of pollutants. It also provides the information needed to perform dose assessment calculations, which verify that SNL/California operations do not adversely affect the public. The potential radiological air emissions from SNL/California are tritium and depleted uranium. Potential pollutant emissions to the sanitary sewer or storm-water runoff collection system include tritium, metals, various organic compounds, solids, and minerals.

Because the two DOE sites in Livermore (LLNL and SNL/California) are so close to each other, distinguishing between their environmental impacts is frequently impossible. There- 
fore, SNL/California and LLNL have established a cooperative arrangement for environmental monitoring. (Note: LLNL is also a prime contractor, but is operated by the University of California and reports to a different DOE Operations Office.) They have prepared and signed a Joint Statement of Responsibilities for Environmental Monitoring at Livermore.17 This Statement documents each facility's roles and responsibilities for environmental monitoring. Each site monitors its own effluents and performs on-site surveillance. Because LLNL has facilities available for analyzing extremely low-level radiological samples, LLNL collects and processes most of the off-site environmental samples, and subsequently transmits the data to SNL/California. SNL/California supplements the LLNL surveillance system by doing site-specific surveillance (sewer monitoring, stack monitoring, groundwater monitoring, and perimeter external radiation surveillance).

Meteorological information representative of conditions at SNL/California is used for assessing the transport, diffusion, and deposition of materials released to the atmosphere by SNL/California operations. Sandia maintains a meteorological tower for collecting the required data. The Environmental Monitoring Group is responsible for meteorological maintenance, calibration, and data archiving.

\subsection{Environmental Monitoring Plan}

DOE Order 5400.1 requires each site using hazardous materials to prepare a site-specific environmental monitoring plan. ${ }^{1}$ This plan is to document all aspects of effluent monitoring and environmental surveillance. It must include a thorough description of the monitoring program, rationale, design criteria, and quality assurance. SNL/California's Environmental Monitoring Plan has been prepared by the Environmental Protection Department. ${ }^{18}$ It was approved by DOE/AL on April 7, 1992.

The Environmental Monitoring Plan describes all elements of the SNL/California Environmental Monitoring Program, as described above. The plan also summarizes the regulatory requirements (DOE, Federal, State, and local) for monitoring, and SNL/California's compliance with these requirements.

The Environmental Monitoring Plan addresses four essential elements:

1. Radiological Monitoring. The plan addresses the requirements for radiological effluent monitoring and environmental surveillance contained in DOE Orders 5400.5 and DOE/EH-0173T.19,20 The plan will also ensure compliance with the requirements of Title 40 CFR, Part 61 (NESHAPs), 9 including an assessment of radiological impact to the public, done using EPA-approved methods.

2. Nonradiological Monitoring. The plan addresses environmental and effluent monitoring of nonradiological hazardous materials to ensure compliance with Federal, State, and local regulations.

3. Meteorological Monitoring. Accurate meteorological data serve many purposes, such as directing environmental monitoring activities, radiological assessment, and emergency response. The meteorological system is part of the Atmospheric Release Advisory Capability (ARAC), a DOE-run network of 
meteorological stations designed to provide information to emergency response personnel in case of a release of radioactive or toxic materials. Meteorological instruments and supporting equipment conform to ARAC specifications. The Environmental Monitoring Plan describes the existing program for meteorological data acquisition. It also addresses instrument maintenance and calibration, and data management.

4. Groundwater Monitoring Program. SNL/California has a Groundwater Monitoring Program, as described in Section 4.1.

\subsubsection{Environmental Data Management}

Effluent and environmental monitoring data are collected to verify the effectiveness of pollution control measures and to assess the potential impact on the public and environment of operations at SNL/California. These activities also ensure compliance with all applicable environmental laws and regulations. The Environmental Monitoring Plan identifies the applicable regulations and the actions to demonstrate compliance.

The Environmental Protection Department is responsible for managing environmental data. Each year, these data are summarized in the Site Envi nental Report (see Section 3.2). 9 This report also summarizes $\mathrm{SNL} /$ California compliance with environmental laws and regulations.

SNL/California has developed a Quality Assurance Management Plan for the ES\&H and Facilities Center (see Section 6.0).21 This plan does not address general data review and management practices. Specific procedures for data verification and management are incorporated in a Quality Assurance Project Plan (QAPP) and operational procedures for the Environmental Monitoring Program.22

Data management done by LLNL is covered by the Surveiliance Monitoring Group's (formerly the Environmental Quality Verification Group) Quality Assurance Plan and Procedures Manual.23,2: These documents meet the requirements of ANSI/ASME NQA-1,25 DOE, and EPA for data analysis. In general, scientific personnel in the Environmental Monitoring Group review the data as they are received. If the data are unusual, LLNL personnel investigate why (including reanalysis, resampling, and record examination). They determine and document the final disposition of the data according to regulatory guidelines.

The data for the current calendar year for each type of monitoring are kept in the office of the appropriate scientist until the annual Site Environmental Report is completed, at which time, the data is microfilmed. ${ }^{10}$ The microfilm is kept on file in the Environmental Monitoring Group, and the originals are sent to a different location for permanent storage.

\subsubsection{Environmental Monitoring Plan Schedule}

In accordance with DOE Order 5400.1, all environmental monitoring requirements will be implemented within three years of the issuance of the Order. The plan was submitted to DOE on April 7, 1992. It will be reviewed annually and updated at least every three vears. If needed, additional budget and resources will be requested through the regular budgetary process. 


\subsection{Environmental Monitoring Activities}

The Environmental Monitoring Program is conducted jointly by SNL/California and LLNL. These are separate DOE facilities that report to different DOE Field Offices. However, because the two sites are next to each other and have similar operations, they share environmental monitoring activities. LLNL conducts the majority of the off-site environmental monitoring. SNL/California augments this program by performing site-specific monitoring.

\subsubsection{Implementation}

The LLNL and SNL/California Environmental Monitoring Program examines the significant pathways by which contaminants can enter the environment by sampling ambient air, surface water, soil, sewage, groundwater, vegetation, and local foodstuffs. An extensive network of environmental dosimeters also measures external radiation levels. SNL/California monitors activities specific to its operations. For instance, SNL/California monitors all potentially contaminated airborne and liquid effluents by 1) measuring airborne tritium at the site boundary, 2) sampling storm-water runoff from the site, 3) sampling sanitary sewer effluents, and 4) monitoring external radiation at the site perimeter.

The Environmental Monitoring Program was thoroughly reviewed as part of the development of the Environmental Monitoring Plan. ${ }^{18}$ This plan identifies any needed changes to the existing monitoring and compliance activities. It is reviewed annually and updated every three years. The Environmental Protection Department is responsible for implementing the Environmental Monitoring Plan.

\subsubsection{Reporting}

The environmental monitoring data and compliance activities are published in the Site Environmental Report (see Section 3.2).10 This report serves as the vehicle for disseminating the environmental monitoring data and the SNL/California compliance record. It is sent to DOE and appropriate regulatory agencies and is made available to the general public.

Radiological emissions from SNL/California are summarized for the calendar year and reported to the DOE EIS (see Section 2.0).

The Environmental Protection Department is responsible for managing the environmental monitoring data and preparing the summary reports. 


\subsection{QUALITY ASSURANCE AND DATA VERIFICATION}

\subsection{Quality Assurance Program}

DOE Orders $5400.1^{1}$ and $5400.5^{19}$ require a quality assurance program for environmental monitoring that is consistent with DOE Order $5700.6 \mathrm{C} .26$ These requirements are implemented through the ES\&H and Facilities Center's Quality Assurance Management Plan, which became effective April 23, 1991. This plan meets the requirements of DOE Order 5700.6C.26 ANSI/ASME NQA-1 1989 was used as the primary guidance for preparing this plan. ${ }^{25}$ The requirements of the Quality Assurance Management Plan are augmented through the use of implementing procedures, which dictate center-wide requirements, and operating procedures, which provide task-specific instructions.

The quality assurance elements of the SNL/California Environmental Monitoring Program are documented in the Program's QAPP.22 This plan implements the requirements of the Center's Quality Assurance Management Plan.21 It was prepared following the guidance of DOE Order $5700.6 \mathrm{C}$ and ANSI/ASQC-E4-19xx. ${ }^{26,27}$ It covers quality assurance guidelines of DOE/EH-0173T. ${ }^{20}$ The QAPP establishes program responsibilities to ensure data are accurate, complete, precise, and representative.

The collection of environmental samples by LLNL's Environmental Monitoring Group is covered by the Environmental Quality Verification Group Quality Assurance Plan.23 This plan meets the requirements of DOE/EH-0173T, ${ }^{20}$ ANSI/ASME NQA-1,25 and EPA guidelines for the preparation of quality assurance program plans. The provisions of this plan have been implemented through the Environmental Monitoring Plan, "Appendix BProcedures." 21

Environmental sample processing done by LLNL's Nuclear Chemistry Department is covered by the Radiological Analytical Services Laboratory Quality Assurance Project Plan. ${ }^{28}$ This plan also meets the requirements of DOE/EH-0173T,20 ANSI/ASME NQA-1,25 and EPA guidelines for preparing quality assurance program plans.

Contract laboratories doing analyses for LLNL and SNL/California's environmental monitoring program are accredited by Cal-EPA. To receive accreditation, the laboratory must have an implemented quality assurance plan. Periodically, Cal-EPA inspects accredited laboratories to make sure they are operating within quality assurance requirements.

\subsection{Laboratory Certification}

All environmental samples collected for regulatory compliance purposes are collected using guidance issued by the EPA. They are analyzed by off-site contract laboratories certified by Cal-EPA. To assure that the laboratory is certified for the requested analysis, $\mathrm{SNL} /$ California uses the Cal-EPA semiannual report that lists the specific analyses each laboratory is certified to perform. SNL/California permanently retains the analytical data and associated quality assurance documentation.

SNL/California does some analyses on-site, for internal purposes only. SNL/California personnel do not perform analyses for determining compliance with any environmental 
regulations, permits, or orders. Therefore, SNL/California is not (and does not intend to become) a State-certified laboratory for chemical analysis.

\subsection{DOE Laboratory Quality Assurance Program for Radioactive Materials}

SNL/California performs in-house tritium analysis on a variety of samples, including some environmental samples. As an independent quality check, the on-site laboratory participates in a tritium analysis intercomparison study, which is conducted by the EPA Environmental Monitoring Systems Laboratory in Las Vegas.

LLNL conducts much of the off-site radiological environmental monitoring. LLNL's quality assurance procedures are documented in the Environmental Quality Verification Group Quality Assurance Plan.23 As part of this program, LLNL participates in intercomparison laboratory assessments sponsored by the EPA's Environmental Radioactivity Laboratory and the DOE Environmental Measurements Laboratory.

\subsection{Independent Data Verification}

"EH-1, in consultation with the appropriate Program Senior Official and field organization, shall develop an independent data verification program as part of environmental monitoring programs at DOE facilities."1

The Laboratory Management Branch of the DOE Office of Technology Development has been established to provide technical support to all environmental analytical laboratory operations throughout DOE. The Branch was also established to assist in developing quality assurance programs and implementing an independent data validation program. SNL is monitoring the progress of this DOE program, and when it is implemented, will participate in the program to ensure independent validation of environmental sampling data.

As noted, LLNL conducts the majority of the off-site environmental monitoring. LLNL addresses independent data verification in its quality assurance plan. At SNL/California, much of the environmental sampling and analysis is conducted by off-site contractors. These contractors are required to have a comprehensive quality assurance plan. The $Q A / Q C$ portion of the environmental monitoring program ensures valid and verifiable data. Additionally, SNL/California's QAPP for environmental monitoring addresses validation of data from LLNL and contract laboratories. 22 It provides an integrated mechanism for implementing quality assurance for all facets of the environmental protection program. The QAPP uses guidance from the ES\&H and Facilities Center's Quality Assurance Management Plan and implementing procedures to establish data quality objectives.21 


\section{REFERENCES}

1. U. S. DOE, Order 5400.1, General Environmental Protection Program (November 1988).

2. U.S. DOE, Sandia National Laboratories, Environment, Safety, and Health Manual, SAND88-1161 (Updated 1993).

3. J. Russell, ALARA Program Implementation, Implementing Procedure IP-25, Sandia National Laboratories, California (January 1993).

4. U. S. DOE, Order 5482.1B, Environment, Safety, and Health Appraisal Program (September 1986).

5. U. S. DOE, Sandia National Laboratories/California, OMB Circular A-106 Report (annual).

6. U. S. DOE, Order 5484.1, Chapter I, Environmental Protection, Safety, and Health Protection Information Reporting Requirements (1981).

7. U.S. DOE, Order 5000.3B, Occurrence Reporting and Processing of Operations Information (February 1992).

8. U. S. EPA, Title 40 CFR, Comprehensive Environmental Response, Compensation, and Liability Act of 1980 (CERCLA), Parts 112, 117 and 302 (1980).

9. U. S. EPA, Title 40 CFR, Part 61, National Emission Standards for Hazardous Air Pollutants (NESHAPs), Subpart H, "Standards for Radionuclides" (1983).

10. D. D. Brekke and R. C. Holland, Site Environmental Report for 1992, Sandia National Laboratories/California, SAND93-8015 (October 1993).

11. U. S. DOE, Environmental Restoration and Waste Management Five-Year Plan (July 1990).

12. Executive Order 12088 (October 13, 1976).

13. D. D. Brekke, Groundwater Protection Management Program Plan, Sandia National Laboratories/California (1992).

14. State of California, San Francisco Bay Region, Regional Water Quality Control Board, Order 88-142 (September 21, 1988).

15. State of California, San Francisco Bay Region, Regional Water Quality Control Board, Order 89-184 (December 13, 1989).

16. U. S. DOE, Sandia National Laboratories/California, Waste Minimization Program Plan (May 1991).

17. U. S. DOE, Joint Statement of Responsibilities for Environmental Monitoring at Livermore, SNL/California and LLNL (August 1, 1993).

18. R. C. Holland, Environmental Monitoring Plan, Sandia National Laboratories, California, SAND91-8013 (June 1992).

19. U.S. DOE, Order 5400.5, Radiation Protection of the Public and the Environment (February 1990).

20. U.S. DOE, Environmental Regulatory Guide for Radiological Effluent Monitoring and Environmental Surveillance, DOE/EH-0173T (1991).

21. R. C. Holland, Quality Assurance Management Plan, Sandia National Laboratories/California (June 1993).

22. R. C. Holland, Environmental Monitoring Program Quality Assurance Project Plan, Sandia National Laboratories/California, SAND93-8010 (June 1993).

23. R. C. Holland, Environmental Quality Verification Group Quality Assurance Plan, Lawrence Livermore National Laboratory, UCAR-10203 (September 1987).

24. D. D. Brekke, M. G. Brown, T. M. Carlsen, and R. C. Holland, Environmental Quality Verification Group Procedures Manual, Lawrence Livermore National Laboratory, UCAR-10254 (1988).

25. American Society of Mechanical Engineers, Quality Assurance Program Requirements for Nuclear Facilities, ANSI/ ASME NQA-1 (1986).

26. U. S. DOE, Order 5700.6C, Quality Assurance (August 1992).

27. American Society of Quality Control, Quality Assurance Program Requirements for Environmental Programs, ANSI/ASQC E4-19xx (Draft, 1991).

28. J. Merrigan, Radiological Analytical Services Laboratory Quality Assurance Project Plan, Lawrence Livermore National Laboratory (1991). 


\section{ACRONYMS AND ABBREVIATIONS}

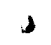

AIP

ALARA

ARAC

BAAQMD

Cal-EPA

CAS

CERCLA

CFR

CWA

DOE

DOE/AL/KAO

$\mathrm{DOE} / \mathrm{HQ}$

EIS

EMS

EOC

EPA

ES\&H

GPMPP

LAP

LLNL

LWRP

MSDS

NEPA

NESHAPs

OI

OR

ORPS

POTWs

QA/QC

QAPP

RCRA

RWQCB

SCEC

SDWA

SNL

SOPS

TRL

WMSC

Agreement in Principle

As low as reasonably achievable

Atmospheric Release Advisory Capability

Bay Area Air Quality Management District

California Environmental Protection Agency

Central Alarm System

Comprehensive Environmental Response, Compensation, and Liability Act

Code of Federal Regulations

Clean Water Act

Department of Energy

DOE Albuquerque Operations Office, Kirtland Area Office

DOE Headquarters (EH-1)

Effluent Information System

Environmental Monitoring Section (LLNL)

Emergency Operations Center

Environmental Protection Agency

Environment, Safety and Health

Groundwater Protection Management Program Plan

Livermore Assessment Program

Lawrence Livermore National Laboratory

Livermore Water Reclamation Plant

Material Safety Data Sheet

National Environmental Policy Act

National Emission Standards for Hazardous Air Pollutants

Occurrence Investigator

Occurrence Report

Occurrence Report and Processing System

Publicly-owned Treatment Works

quality assurance/quality control

Quality Assurance Project Plan

Resource Conservation and Recovery Act

Regional Water Quality Control Board

SNL/CA ES\&H Council

Safe Drinking Water Act

Sandia National Laboratories

Safe Operating Procedures

Tritium Research Laboratory

Waste Minimization Steering Committee 


\section{UNLIMITED RELEASE}

\section{INITIAL DISTRIBUTION}

U.S. Department of Energy (5)

Albuquerque Operations Office

Attn.: J. Andrews

K. Carlson

J. Johnsen

G. Laskar

S. E. Umshler

P.O. Box 5400

Albuquerque, NM 87115

MS0141, R. Park, Org. 11300

MS0141, T. Vandenberg, Org. 11300

MS1067, L. Jones, Org. 7000

MS1066, J. Baremore, Org. 7200

MS1065, R. Rohde, Org. 7254

MS1315, T. Blejwas, Org. 7500

MS1054, J. Stiegler, Org. 7700

MS1305, J. D. Fish, Org. 7574

MS1305, S. Hwang, Org. 7575

MS1309, Environmental Operations Programs Library, Org. 7512

MS9001, J. C. Crawford, Org. 8000

Attn.: D. L. Crawford, 1900

E. E. Ives, 5200

J. B. Wright, 5300

M. E. John, 8100

R. J. Detry, 8200

W. J. McLean, 8300

L. A. Hiles, 8400

P. E. Brewer, 8500

R. C. Wayne, 8700

MS9021, K. W. Gordon, Org. 8535

MS9901, L. A. West, Org. 8600

MS9041, D. Putz, Org. 8609

MS9222, D. D. Brekke (50), Org. 8642

MS9021, Technical Communications for OSTI, Org. 8535 (10)

MS9021, Technical Communications/Technical Library Processes

MS0899, Technical Library Processes Department, Org. 7141 (4)

MS9018, Central Technical Files, Org. 8523-2 (3) 


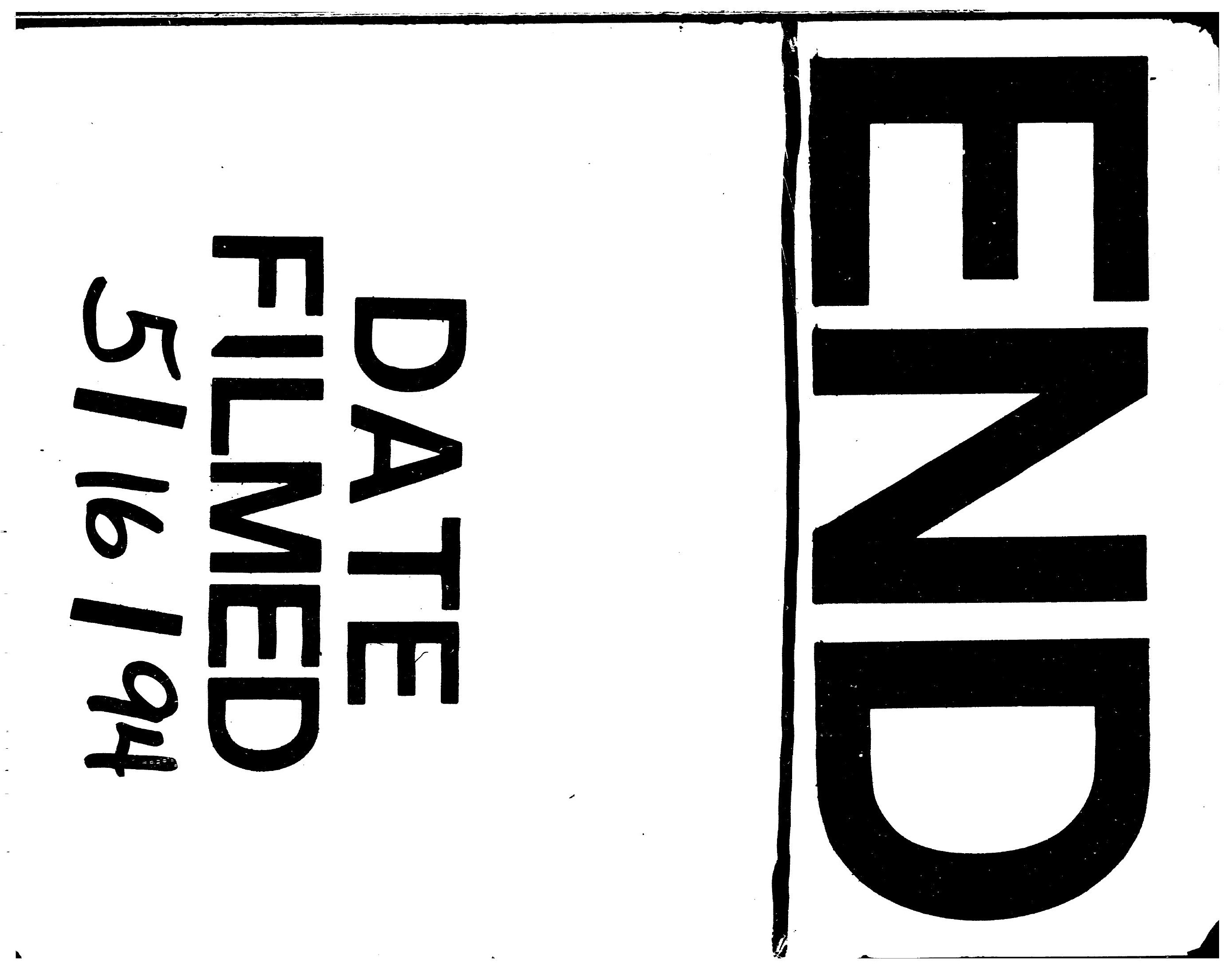


